\title{
Spiroplasma corruscae sp. nov., from a Firefly Beetle (Coleoptera: Lampyridae) and Tabanid Flies (Diptera: Tabanidae)
}

\author{
K. J. HACKETT, ${ }^{1 *}$ R. F. WHITCOMB,${ }^{1}$ F. E. FRENCH,${ }^{2}$ J. G. TULLY, ${ }^{3}$ G. E. GASPARICH, ${ }^{1}$ D. L. ROSE, ${ }^{3}$ \\ P. CARLE,${ }^{4}$ J. M. BOVÉ ${ }^{4}$ R. B. HENEGAR, ${ }^{1}$ T. B. CLARK,${ }^{1} \dagger$ M. KONAI,${ }^{1}$ E. A. CLARK,${ }^{1}$ \\ AND D. L. WILLIAMSON ${ }^{5}$
}

Insect Biocontrol Laboratory, U.S. Department of Agriculture, Beltsville, Maryland 20705 ${ }^{1}$; Department of Biology, Georgia Southern College, Statesboro, Georgia 30460'; Mycoplasma Section, Laboratory of Molecular Microbiology, National Institute of Allergy and Infectious Diseases, Frederick Cancer Research Facility, Frederick, Maryland 21702 ${ }^{3}$; Laboratoire de Biologie Cellulaire et Moléculaire, Institut Nationale de Recherche Agronomique, 33883 Villenave d'Ornon, France ${ }^{4}$; and Department of Anatomical Sciences, State University of New York, Stony Brook, New York $11794^{5}$

\begin{abstract}
Spiroplasma strain EC-1 ${ }^{\mathrm{T}}(\mathrm{T}=$ type strain), which was isolated from the gut of a lampyrid beetle (Ellychnia corrusca) in Maryland, was serologically distinct from other spiroplasma species and groups. Similar strains were obtained from other $E$. corrusca specimens, and, later, numerous isolates of similar or partially related strains were obtained from several species of tabanid flies. Cells of strain EC-1 ${ }^{\mathrm{T}}$ were helical, motile filaments that were bound by a single cytoplasmic membrane, and there was no evidence of a cell wall. The cells were filterable through 220-nm-pore-size membrane filters but not through 100-nm-pore-size membrane filters. The organism was absolutely resistant to penicillin $(1,000 \mathrm{U} / \mathrm{ml})$ and required sterol for growth. Strain EC-1 ${ }^{\mathrm{T}}$ grew well in M1D and SP-4 liquid media and could be cultivated in the Edward formulation of conventional mycoplasma medium and in $1 \%$ serum fraction medium. Optimal growth occurred at $32^{\circ} \mathrm{C}$ (doubling time, $1.5 \mathrm{~h}$ ). Strain EC-1 $1^{\mathrm{T}}$ multiplied at 10 to $41^{\circ} \mathrm{C}$, but not at 5 or $43^{\circ} \mathrm{C}$. This organism produced acid from glucose, but did not hydrolyze arginine or utilize urea. The guanine-plus-cytosine content of the DNA was determined to be $26.3 \mathrm{~mol} \%$ by the melting temperature method and $27.0 \mathrm{~mol} \%$ by the buoyant density method. As a result of our studies, strain EC-1 (= ATCC 43212) is designated the type strain of a new species, Spiroplasma corruscae.
\end{abstract}

Firefly beetles (Coleoptera: Lampyridae) are an extremely rich source of mollicutes (19). Several Spiroplasma species (5, $6,17-19,45$ ) and Mesoplasma species (34) (formerly described as Acholeplasma species $[1,8,19,30,35])$ have been isolated from members of this insect family. Also, the first named Entomoplasma (28) species, Entomoplasma ellychniae (34) (formerly described as a mycoplasma [32]), was isolated $(5,19)$ in 1983 from the lampyrid beetle, Ellychnia corrusca. Subsequently, three additional serovar clusters containing organisms isolated from luminescent lampyrid species were elevated to species status as members of the genus Mycoplasma (42) and were later transferred to the genus Entomoplasma (28).

Ellychnia corruscae is a somewhat unusual lampyrid beetle in that it is nonluminescent. Beginning in late winter 1983, adults of this species were collected while they were emerging from their overwintering sites at the base of a white oak (Quercus $a l b a)$ tree in Beltsville, Md., and their gut and hemocoel fluids were analyzed for mollicutes. Spiroplasmas were isolated from the gut contents of 9 of the 30 specimens examined and from the hemolymph of 2 specimens $(16 \mathrm{a}, 17)$. Several serologically related spiroplasmas were subsequently obtained $(5,7,17-19)$, including strain $\mathrm{EC}-1^{\mathrm{T}}(\mathrm{T}=$ type strain) and isolates $\mathrm{EC}-2$, EC-7, EC-8, EC-9, and EC-10 from gut contents and strain EC-1a and isolate EC-4 from hemocoel contents. Strains and isolates related to strain EC- $1^{\mathrm{T}}$ proved to be serologically unlike members of previously described groups or subgroups.

* Corresponding author. Mailing address: Building 011A, Room 214, BARC-West, Beltsville, MD 20705. Phone: (301) 504-6325. Fax: (301) 504-5104.

$\dagger$ Deceased.
Strain EC-1 ${ }^{\mathrm{T}}$ was designated the representative of spiroplasma group XIV in a revised classification (31) of spiroplasma groups.

The ecology of strain EC-1 ${ }^{\mathrm{T}}$ and its relatives has been studied extensively. Of particular significance is the occurrence of this spiroplasma in a wide range of deerflies and horseflies $(7,11,12$, $36,38,40,41)$, important economic pests of livestock and humans. The occurrence of this spiroplasma in tabanid flies is being studied as a model for understanding spiroplasma-insect interactions.

In this paper we report the results of taxonomic studies of strain $\mathrm{EC}-1^{\mathrm{T}}$ and related strains that satisfy proposed requirements for species descriptions for the class Mollicutes (20). Our results support designation of strain EC-1 (= ATCC 43212) as the type strain of a new species, Spiroplasma corruscae.

\section{MATERIALS AND METHODS}

Spiroplasma strains. Techniques for isolating spiroplasmas from insect guts and hemocoels have been described previously (17). Strain EC-1 ${ }^{\mathrm{T}}$ was isolated and cultivated by T. B. Clark from the gut of an adult firefly beetle (Ellychnia corrusca [Coleoptera: Lampyridae]) $(5,7)$. Other strains and isolates obtained from this beetle species $(5,19)$ and from tabanid flies $(7,11,12,17,22,23,38$, $40)$ were characterized serologically. Representative strains $(16,28,29,33,43)$ of previously recognized groups and subgroups, including type strains of previously recognized species $(29,33,43)$, were cultivated for comparative purposes.

Culture media and cultivation techniques. Strain EC-1 ${ }^{\mathrm{T}}$ was grown in primary culture (24) and was subsequently cloned (26) in SM-1 liquid medium (37) at $30^{\circ} \mathrm{C}$. Other media used in this study included M1D medium (37), SP-4 medium (37), the Edward formulation of conventional mycoplasma medium (HSI medium) containing $20 \%$ horse serum $(10,37)$, and serum-fraction broth supplemented with $1 \%$ bovine serum fraction (27). Solid formulations of these media were prepared by adding Noble agar (Difco Laboratories, Detroit, Mich.) to a final concentration of $2.25 \%$. Cultures on solid media were incubated aerobically and anaerobically by using a BBL Anaerobic GasPak system (Becton Dickinson and Co., Gaithersburg, Md.) containing 25 to $35 \% \mathrm{H}_{2}, 4$ to $7 \% \mathrm{CO}_{2}$, and $<1 \% \mathrm{O}_{2}$.

Temperature requirements for growth were determined by preparing 10 -fold dilutions of strain EC-1 ${ }^{\mathrm{T}}$ in M1D broth and incubating the dilution series at 5,10 , 
$15,20,25,30,32,37,41$, and $43^{\circ} \mathrm{C}$. Growth of the organisms was determined by observing indicator changes in the media and by examining the cultures microscopically during a 45-day observation period. Doubling times at each temperature were estimated by observing the time required for medium acidification and fitting the temperature-growth curve to a logistic growth equation (21).

Morphological studies. Cells of strain EC-1 ${ }^{\mathrm{T}}$ from cultures in the logarithmic phase were examined by dark-field microscopy (magnification, $\times 1,250$ ). Electron microscopic techniques for spiroplasmas have been described previously (9).

Sterol requirement. Sterol requirements for growth were determined by a standard broth culture method (27).

Tests for biological, biochemical, and serological properties. Procedures for determining carbohydrate fermentation (1), arginine hydrolysis and urea utilization (1), hemadsorption (14), and film and spot production (13) have been described previously. Filtration characteristics (26) were determined by using cultures in M1D broth.

Spiroplasma deformation (DF) (46) and metabolism inhibition (MI) (44) tests were used to compare strains serologically with all previously described spiroplasma groups and subgroups. Hyperimmune antisera to all previously established Spiroplasma species and existing and putative groups and subgroups (29) were obtained from reference collections at the U.S. Agricultural Research Center in Beltsville, Md., and the National Institute of Allergy and Infectious Diseases laboratory in Frederick, Md. In the DF test (46), a specific homologous antiserum deformed spiroplasma cells into spheroidal forms, which could be readily identified. Quantitative relationships among various serum dilutions were determined by examining, by dark-field microscopy, samples containing serum dilutions and a measured number of organisms, which was kept constant in each test. For the MI test (44), diluted antisera and complement were added to an SP-4 broth culture containing phenol red as a $\mathrm{pH}$ indicator, and the preparation was incubated at $30^{\circ} \mathrm{C}$. The MI titer was the reciprocal of the final antiserum dilution in which there was no change in the $\mathrm{pH}$ indicator.

Genomic analysis. Extraction and purification of DNA from mollicutes were performed as described previously (2). Estimates of the guanine-plus-cytosine $(\mathrm{G}+\mathrm{C})$ content of purified DNA of strain $\mathrm{EC}-1^{\mathrm{T}}$ were obtained by two procedures, the buoyant density and melting temperature procedures (3).

\section{RESULTS AND DISCUSSION}

Cultural and morphological properties. Strain EC- $1^{\mathrm{T}}$ grew rapidly in liquid SM-1, M1D, and SP-4 media. Dark-field microscopy of logarithmic-phase cultures of strain $E C-1^{T}$ revealed helical filamentous cells with six or more turns. The cells were delimited by only a membrane, and there was no evidence of a cell wall in electron micrographs (31). Strain $\mathrm{EC}-1^{\mathrm{T}}$ also grew (more slowly) in the Edward formulation of conventional mycoplasma medium containing horse serum or in $1 \%$ bovine serum fraction medium. Growth occurred at temperatures ranging from 10 to $41^{\circ} \mathrm{C}$, but not at 5 or $43^{\circ} \mathrm{C}$; optimal growth was observed at $32^{\circ} \mathrm{C}$. The doubling times at $10,15,20,25,30,32$, and $37^{\circ} \mathrm{C}$ were $33.6,13.9,5.5,3.1,1.9,1.5$, and $5.2 \mathrm{~h}$, respectively. Strain EC-1 ${ }^{\mathrm{T}}$ grew on solid medium containing $2.25 \%$ Noble agar incubated at $30^{\circ} \mathrm{C}$. Aerobically, colonies grew slowly and were slightly diffuse. Anaerobically, colonies grew faster, and, although they were discrete, there were two types, rough colonies and dew drop (slightly friedegg) colonies (Fig. 1).

Biochemical and biological properties. Strain $E C-1^{T}$ produced acid from glucose, but did not hydrolyze arginine or utilize urea (31). This organism did not produce a film and spot reaction, and colonies on an agar-containing medium did not hemadsorb guinea pig erythrocytes. Strain EC-1 ${ }^{\mathrm{T}}$ passed readily through 450 - and 300 -nm-pore-size membrane filters. Passage through 220-nm-pore-size filters reduced the viable cell titer 10 -fold to $10^{-9}$ color-changing units per ml; a 100 nm-pore-size membrane filtrate was free of viable cells.

Serological studies. Strain EC-1 ${ }^{\mathrm{T}}$, which had homologous titers of $1: 2,560$ in the spiroplasma DF test and 1:13,000 in the MI test (31), exhibited weak serological reactivity with representatives of 12 other spiroplasma groups or subgroups (Table 1). None of the reactions was reciprocal, and only two reactions, the reactions of strain EC- $1^{\mathrm{T}}$ antiserum with group VII type strain MQ-1 and with ungrouped strain PLHS-1, occurred in both DF and MI tests. Strain EC-1 ${ }^{\mathrm{T}}$ is therefore serologically unrelated to all previously described species and existing

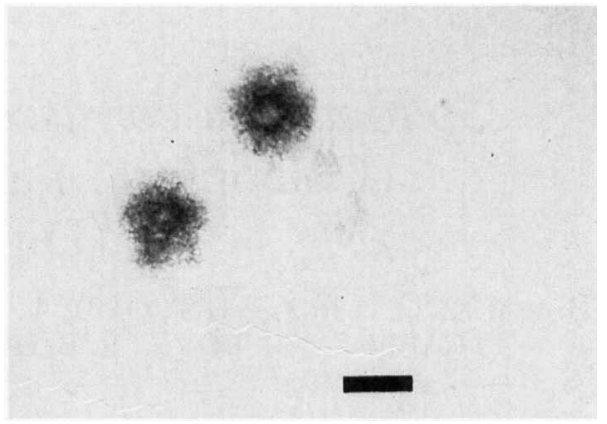

FIG. 1. Colonies of strain EC-1 ${ }^{\mathrm{T}}$ on HSI solid medium containing $2.25 \%$ Noble agar after 4 days of incubation at $30^{\circ} \mathrm{C}$ under anaerobic conditions. Bar $=100 \mu \mathrm{m}$.

or putative groups or subgroups. Many tabanid spiroplasma isolates have proven to be closely related to strain $\mathrm{EC}-1^{\mathrm{T}}$. These isolates include isolates TS-1 (DF titer, 1:2,560), TS-2 (DF titer, 1:1,280), TS-2B (DF titer, 1:1,280), and TC-1 (DF titer, 1:1,280). The DF titers of tabanid isolates with strain EC $-1^{\mathrm{T}}$ antiserum have been reported previously $(15,40)$ to vary from $1: 320$ to $1: 5,120$, and there is evidence of biogeographical influence.

Sterol requirement. Strain EC-1 ${ }^{\mathrm{T}}$ responded positively to cholesterol supplementation of serum-free SP-4 medium (Table 2). This organism failed to grow in base broth alone, but grew when 1 to $20 \mu \mathrm{g}$ of cholesterol per $\mathrm{ml}$ was included.

DNA base composition. The $\mathrm{G}+\mathrm{C}$ base composition of the DNA of strain EC-1 $1^{\mathrm{T}}$ was $27 \pm 1 \mathrm{~mol} \%$ as determined by the buoyant density method and $26.3 \pm 1 \mathrm{~mol} \%$ as determined by the melting temperature method (31).

Habitat. Although a search of other lampyrid and beetle species did not yield additional group XIV isolates (19), serologically similar isolates and some partially related isolates were obtained from many species of horseflies and deerflies (Diptera: Tabanidae) from Maryland. These isolates included

TABLE 1. Serological reactions of strain EC-1 ${ }^{\mathrm{T}}$

\begin{tabular}{llccccc}
\hline \multirow{2}{*}{ Group } & \multirow{2}{*}{ Strain } & \multicolumn{2}{c}{ Spiroplasma DF test titer } & & \multicolumn{2}{c}{ MI test titer } \\
\cline { 3 - 4 } \cline { 6 - 7 } & & Antiserum & Antigen & & Antiserum & Antigen \\
\hline I-5 & LB-12 & $40^{a}$ & $0^{b}$ & & $0^{c}$ & $0^{d}$ \\
IV & B31 & 40 & 0 & & 0 & 0 \\
VII & MQ-1 & 40 & 0 & & 54 & 0 \\
IX & CN-5 & 40 & 0 & & 0 & 0 \\
XI & MQ-4 & 40 & 0 & & 0 & 0 \\
XIV & EC-1 & $2,560^{e}$ & $2,560^{e}$ & & $39,000^{e}$ & $39,000^{e}$ \\
XX & LD-1 & 40 & 0 & & 0 & 0 \\
XXII & CT-1 & 160 & 0 & & 0 & 0 \\
XXIII & TG-1 & 0 & $40(20,480)^{f}$ & & 0 & 0 \\
NG & HYOS-1 & 20 & 0 & & 0 & 0 \\
NG & PLHS-1 & 80 & 0 & & 162 & 0 \\
NG & TALS-2 & 0 & $160(320)$ & & 0 & 0 \\
NG & TIUS-1 & 0 & 0 & & 54 & 0 \\
\hline
\end{tabular}

${ }^{a}$ Reciprocal of the end point in the DF test in which the antigen indicated was tested against strain $\mathrm{EC}-1^{\mathrm{T}}$ antiserum.

${ }^{b}$ Reciprocal of the end point in the DF test in which the antiserum indicated was tested against strain EC- $1^{\mathrm{T}}$ antigen.

${ }^{c}$ Reciprocal of the end point in the MI test in which the antigen indicated was tested against strain EC-1 ${ }^{\mathrm{T}}$ antiserum.

${ }^{d}$ Reciprocal of the end point in the MI test in which the antiserum indicated was tested against strain EC-1 ${ }^{\mathrm{T}}$ antigen.

${ }^{e}$ Homologous titer of strain EC-1 $1^{\mathrm{T}}$ in the test system used.

${ }^{f}$ The values in parentheses are the homologous titers of antisera against which strain EC-1 ${ }^{\mathrm{T}}$ cross-reacted when it was used as the antigen in heterologous tests. ${ }^{g} \mathrm{NG}$, not grouped. 
TABLE 2. Growth response of strain EC-1 ${ }^{\mathrm{T}}$ to cholesterol ${ }^{a}$

\begin{tabular}{lcc}
\hline $\begin{array}{c}\text { Supplement(s) added to serum- } \\
\text { free base medium }\end{array}$ & $\begin{array}{c}\text { Cholesterol } \\
\text { concn } \\
(\mu \mathrm{g} / \mathrm{ml})\end{array}$ & $\begin{array}{c}\text { Amt of } \\
\text { protein } \\
(\mathrm{mg} / 100 \mathrm{ml})\end{array}$ \\
\hline None & 0 & $\mathrm{IG}^{b}$ \\
Bovine serum fraction $(1 \%)$ & 0 & 2.80 \\
Albumin $(1 \%)$ and palmitic & 0 & 0.26 \\
$\quad$ acid $(10 \mu \mathrm{g} / \mathrm{ml})$ & 0 & 0.28 \\
Albumin $(1 \%)$, Tween 80 & & \\
$\quad(0.1 \%)$, and palmitic acid & 1 & 1.10 \\
$(10 \mu \mathrm{g} / \mathrm{ml})$ & 5 & 1.55 \\
& 10 & 2.23 \\
& 20 & 1.84 \\
\hline
\end{tabular}

${ }^{a}$ All flasks received an inoculum from $1 \%$ bovine serum fraction broth, were incubated at $30^{\circ} \mathrm{C}$, and were harvested by centrifugation after 2 days.

${ }^{b} \mathrm{IG}$, insufficient growth for detection.

strain TATS-1 from Tabanus atratus (gut contents); strain TC-1 from Tabanus calens (gut contents); isolates TG-1 (gut contents) and TG-2 (hemocoel contents) from Tabanus gladiator; strain TS-1 (gut contents) and isolates TS-2 (gut contents) and TS-2B (hemocoel contents) from Tabanus sulcifrons; and isolates from the gut contents and blood of three Tabanus sulcifrons specimens (Insect Biocontrol Laboratory accession numbers 00153,00161 , and 00187$)(7,17,40)$. Isolates were also obtained from tabanid species from Georgia north to Maryland, including Chlorotabanus crepuscularis, Tabanus lineola, Tabanus melanocerus, Tabanus molestus, Tabanus nigripes, Tabanus petiolatus, and Tabanus trimaculatus $(11,12,38,40)$, as well as from insects from South Dakota (Tabanus sulcifrons [40]) and France (Chrysops viduatus, Hybomitra bimaculata, and Tabanus bromius) $(22,23)$. Spiroplasmas sometimes occurred in mixed infections in tabanids $(38,39)$, whereas spiroplasmas, mesoplasmas, and entomoplasmas occurred in mixed infections in the beetle Ellychnia corruscae $(17,19)$. Entomoplasma ellychniae (32) appears to be regularly associated with Ellychnia corrusca. Compared with other groups of insects $(17,18)$, a very high proportion of tabanid specimens was infected with spiroplasmas, with the frequencies of infection commonly exceeding $50 \%$ (11). In one estimate of the number of group XIV spiroplasmas in tabanid gut viscera, a titer of $10^{5}$ cells was obtained, which is typical for estimates of the titers of other spiroplasmas in tabanid guts (11).

Several hypotheses have been offered to explain the occurrence of group XIV spiroplasmas in both tabanid flies and firefly beetles. One of these hypotheses (17) involves possible transmission of spiroplasmas on flower surfaces, which may be visited by adult tabanids and lampyrids. The existence of a spiroplasma transmission cycle involving exposed host plant surfaces is supported by evidence which shows that (i) the spiroplasma persists for up to 30 days on leaf surfaces (36), (ii) transmission is affected by weather, particularly rainfall (11), and (iii) spiroplasmas are transmitted from infected Ellychnia corruscae adults to tabanid flies at feeding sources under laboratory conditions (36).

A second hypothesis (17) is that larvae of members of the two groups, both of which are predaceous, may acquire group XIV spiroplasmas during foraging activities. However, there is no experimental evidence for this. Transmission among lampyrid or tabanid larvae has not been attempted. In limited sampling of lampyrid and tabanid larvae, group XIV spiroplasmas were not isolated. Nevertheless, other spiroplasmas have been isolated from lampyrid beetle larvae $(19,36)$, and entomoplas- mas have been isolated from lampyrid pupae (36). And although strain EC-1 ${ }^{\mathrm{T}}$ injected into beetle pupae (Tenebrio molitor [Coleoptera: Tenebrionidae]) was not transmitted to firefly (Photuris hebes) larvae that fed on the pupae, the group XIX firefly spiroplasma was transmitted to larvae by this method (36).

Transmission among tabanid flies has also been investigated. The results of recent studies $(11,36)$ suggest that vertical transmission does not occur; tabanid spiroplasmas were not transmitted transovarially and were not found on fly surfaces. Horizontal fly-to-fly transmission has not been studied.

Overall, it appears that Ellychnia corrusca is the spiroplasma's overwintering host and that tabanid flies are critical in the spiroplasma's spring-to-fall distribution. This is consistent with the isolation of members of similar serovars and genovars of the spiroplasma from the guts of beetles exiting from overwintering sites in early March and April and from the guts and hemocoels of tabanid flies from June to September $(15,17)$. Higher-than-expected variability among serovars and genovars suggests that there are multiple host transmission cycles (15). The spiroplasma's tolerance of a wide range of temperatures (10 to $41^{\circ} \mathrm{C}$ [21]) may reflect a rather broad seasonality and variability of host transmission cycles.

Although group XIV spiroplasmas multiply at $37^{\circ} \mathrm{C}$ (the vertebrate body temperature), fly-to-fly transmission via vertebrate hosts is unlikely. There is no experimental evidence that group XIV spiroplasmas can multiply in vertebrates (4), and samples of animal sera in France were serologically negative for antibodies to these spiroplasmas (23). Nevertheless, since other tabanid spiroplasmas do multiply and persist in suckling mice (4), and since animal sera have been found to react positively to group XVI spiroplasmas (23), some of which are associated with blood-sucking mosquitoes, it may be premature to rule out a role for vertebrates in transmission.

The properties of strain EC-1 ${ }^{\mathrm{T}}$ described previously or reported in this paper fulfill proposed criteria (20) for descriptions of species of the class Mollicutes. Properties mandating assignment to this class include the absence of a cell wall, filterability, a lack of reversion to walled bacteria when the organism is grown in antibiotic-free media, and penicillin resistance. The sterol requirement of strain $\mathrm{EC}-1^{\mathrm{T}}$, its inability to utilize urea, and its helicity and motility place this organism in the family Spiroplasmataceae (25). Serological comparisons of strain EC-1 ${ }^{\mathrm{T}}$ with representatives of other Spiroplasma species and groups revealed that strain $\mathrm{EC}-1^{\mathrm{T}}$ is a member of a distinct Spiroplasma species.

In the taxonomic description below the properties of the new organism are summarized.

Description of Spiroplasma corruscae sp. nov. Spiroplasma corruscae ( cor $^{\prime}$ rus. cae. M. L. gen. n. curruscae, from Ellychnia corrusca, a firefly beetle [Coleoptera: Lampyridae], the original source of the organism). Cells are filamentous, helical, and motile, pass through filters with $450-, 300-$, and 220 -nm pores with a 10-fold loss of titer, and do not pass through filters with 100 -nm pores. The cells lack true cell walls. Colonies on solid medium containing $2.25 \%$ Noble agar are slightly diffuse to discrete and generally without the characteristic fried-egg morphology.

Chemoorganotrophic. Acid is produced from glucose. Does not hydrolyze arginine or utilize urea.

Film and spot reaction negative. Does not hemadsorb guinea pig erythrocytes.

The sterol requirement is fulfilled by cholesterol.

Temperature range, 10 to $41^{\circ} \mathrm{C}$; optimum temperature, $32^{\circ} \mathrm{C}$. The doubling time at the optimum temperature is $1.5 \mathrm{~h}$.

Serologically distinct from previously established Spiroplasma species, groups and subgroups. 
Strain EC-1 ${ }^{\mathrm{T}}$ was isolated from gut of an adult lampyrid beetle (Ellychnia corrusca). Many additional isolates and strains have been isolated from the hemolymph of Ellychnia corrusca and from the gut contents and hemolymph of tabanid flies. Pathogenicity for insects is not known.

The $\mathrm{G}+\mathrm{C}$ content of the DNA is $26.3 \pm 1 \mathrm{~mol} \%$ as determined by the melting temperature method and $27.0 \pm 1 \mathrm{~mol} \%$ as determined by the buoyant density method.

The type strain is strain EC-1 (= ATCC 43212).

\section{ACKNOWLEDGMENTS}

This work was supported in part by Binational Agricultural Research and Development grant US-1902-90R and by U.S. Department of Agriculture potato research grants.

We thank Jeffrey Buller, Georgia Southern University, Statesboro, for help with the specific epithet.

\section{REFERENCES}

1. Aluotto, B. B., R. G. Wittler, C. O. Williams, and J. E. Faber. 1970. Standardized bacteriologic techniques for characterization of Mycoplasma species. Int. J. Syst. Bacteriol. 20:35-58.

2. Carle, P., C. Saillard, and J. M. Bové. 1983. DNA extraction and purification. Methods Mycoplasmol. 1:295-299.

3. Carle, P., C. Saillard, and J. M. Bové. 1983. Determination of guanine plus cytosine content of DNA. Methods Mycoplasmol. 1:301-308.

4. Chastel, C., F. Le Goff, and I. Humphrey-Smith. 1992. Multiplication and persistence of bee and tabanid spiroplasmas in the suckling mouse model. Int. Org. Mycolplasmol. Lett. 2:116.

5. Clark, T. B. 1984. Diversity of spiroplasma host-parasite relationships. Isr. J. Med. Sci. 20:995-997.

6. Clark, T. B., R. B. Henegar, L. Rosen, K. J. Hackett, R. F. Whitcomb, J. E. Lowry, C. Saillard, J. M. Bové, J. G. Tully, and D. L. Williamson. 1987. New spiroplasmas from insects and flowers: isolation, ecology, and host association. Isr. J. Med. Sci. 23:687-690.

7. Clark, T. B., R. V. Peterson, R. F. Whitcomb, R. B. Henegar, K. J. Hackett, and J. G. Tully. 1984. Spiroplasmas in the Tabanidae. Isr. J. Med. Sci. 20:1002-1005.

B. Clark, T. B., J. G. Tully, D. L. Rose, R. Henegar, and R. F. Whitcomb. 1986 Acholeplasmas and similar nonsterol-requiring mollicutes from insects: missing link in microbial ecology. Curr. Microbiol. 13:11-16.

9. Clark, T. B., R. F. Whitcomb, J. G. Tully, C. Mouches, C. Saillard, J. M Bové, H. Wróblewski, P. Carle, D. L. Rose, R. B. Henegar, and D. L. Williamson. 1985. Spiroplasma melliferum, a new species from the honeybee (Apis mellifera). Int. J. Syst. Bacteriol. 35:296-308.

10. Edward, D. G. ff. 1947. A selective medium for pleuropneumonia-like organisms. J. Gen. Microbiol. 1:238-243.

11. French, F. E., R. F. Whitcomb, D. V. Hagan, J. A. Rafter, M. Konai, and E. A Clark. 1992. Dynamics of Spiroplasma infections in tabanid (Diptera: Tabanidae) flies, laboratory transmission, and in vitro tests. Int. Org. Mycolplasmol. Lett. 2:114.

12. French, F. E., R. F. Whitcomb, J. G. Tully, K. J. Hackett, E. A. Clark, R. B Henegar, A. G. Wagner, and D. L. Rose. 1990. Tabanid spiroplasmas of the southeast USA: new groups and correlation with host life history strategy ZentralbI. Bakteriol. Suppl. 20:919-921.

13. Freundt, E. A. 1983. Film and spot production. Methods Mycoplasmol $1: 373-374$

14. Gardella, R. S., and R. A. Del Giudice. 1983. Hemagglutination, hemadsorption, and hemolysis. Methods Mycoplasmol. 1:379-384.

15. Gasparich, G. E., K. J. Hackett, F. E. French, and R. F. Whitcomb. Unpublished data.

16. Guo, Y. H., T. A. Chen, R. F. Whitcomb, D. L. Rose, J. G. Tully, D. L. Williamson, X. D. Ye, and Y. X. Chen. 1990. Spiroplasma chinense sp. nov. from flowers of Calystegia hederacea in China. Int. J. Syst. Bacteriol. 40:421-425.

16a.Hackett, K. Unpublished data.

17. Hackett, K. J., and T. B. Clark. 1989. The ecology of spiroplasmas, p. 113-200. In R. F. Whitcomb and J. G. Tully (ed.), The mycoplasmas, vol. 5. Academic Press, Inc., New York.

18. Hackett, K. J., R. F. Whitcomb, R. B. Henegar, A. G. Wagner, E. A. Clark, J. G. Tully, F. Molina, W. McKay, P. Santini, D. L. Rose, J. J. Anderson, and D. E. Lynn. 1990. Mollicute diversity in arthropod hosts. Zentralbl. Bakteriol. Suppl. 20:442-454.

19. Hackett, K. J., R. F. Whitcomb, J. G. Tully, J. E. Lloyd, J. J. Anderson, T. B. Clark, R. B. Henegar, D. L. Rose, E. A. Clark, and J. L. Vaughn. 1992. Lampyridae (Coleoptera): a plethora of mollicute associations. Microb. Ecol. 23:181-193.

20. International Committee on Systematic Bacteriology Subcommittee on the Taxonomy of Mollicutes. 1995. Revised minimum standards for description of new species of the class Mollicutes. Int. J. Syst. Bacteriol. 45:605-612.

21. Konai, M., E. A. Clark, M. Camp, and R. F. Whitcomb. 1996. Temperature ranges and optima of spiroplasmas. Curr. Microbiol. 32:1-7.

22. Le Goff, F., I. Humphrey-Smith, M. Leclercq, and C. Chastel. 1991. Spiroplasmas from European Tabanidae. Med. Vet. Entomol. 5:143-144.

23. Le Goff, F., F. Supplisson, M. Leclercq, M. Marjolet, I. Humphrey-Smith, and C. Chastel. 1992. Characterization and ecology of tabanid spiroplasmas in France. Int. Org. Mycolplasmol. Lett. 2:136.

24. Markham, P. G., T. B. Clark, and R. F. Whitcomb. 1983. Culture techniques for spiroplasmas from arthropods. Methods Mycoplasmol. 2:217-223.

25. Skripal, I. G. 1983. Revival of the name Spiroplasmataceae fam. nov., nom. rev., omitted from the 1980 Approved Lists of Bacterial Names. Int. J. Syst. Bacteriol. 33:408.

26. Tully, J. G. 1983. Cloning and filtration techniques for mycoplasmas. Methods Mycoplasmol. 1:173-177.

27. Tully, J. G. 1983. Tests for digitonin sensitivity and sterol requirement Methods Mycoplasmol. 1:355-362.

28. Tully, J. G., J. M. Bové, F. Laigret, and R. F. Whitcomb. 1993. Revised taxonomy of the class Mollicutes: proposed elevation of a major cluster of arthropod-associated mollicutes to ordinal rank (Entomoplasmatales ord nov.), with provision for familial rank to separate species with nonhelical morphology (Entomoplasmataceae) from helical species (Spiroplasmataceae), and emended descriptions of the order Mycoplasmatales, family $M y-$ coplasmataceae. Int. J. Syst. Bacteriol. 43:378-385.

29. Tully, J. G., and S. Razin (ed.). 1995. Molecular and diagnostic procedures in mycoplasmology, vol. 2, p. 460-462. Academic Press, San Diego, Calif.

30. Tully, J. G., D. L. Rose, P. Carle, J. M. Bové, K. J. Hackett, and R. F. Whitcomb. 1988. Acholeplasma entomophilum sp. nov. from gut contents of a wide range of host insects. Int. J. Syst. Bacteriol. 38:164-167.

31. Tully, J. G., D. L. Rose, E. Clark, P. Carle, J. M. Bové, R. B. Henegar, R. F Whitcomb, D. E. Colflesh, and D. L. Williamson. 1987. Revised group classification of the genus Spiroplasma (class Mollicutes), with proposed new groups XII to XXIII. Int. J. Syst. Bacteriol. 37:357-364.

32. Tully, J. G., D. L. Rose, K. J. Hackett, R. F. Whitcomb, P. Carle, J. M. Bové, David E. Colflesh, and David L. Williamson. 1989. Mycoplasma ellychniae sp. nov., a sterol-requiring mollicute from the firefly beetle Ellychnia comusca. Int. J. Syst. Bacteriol. 39:284-289.

33. Tully, J. G., and R. F. Whitcomb. 1991. The genus Spiroplasma, p. 1960 1980. In A. Balows, H. G. Trüper, M. Dworkin, W. Harder, and K. H. Schleifer (ed.), The prokaryotes, 2nd ed., vol. 2. Springer-Verlag, New York.

34. Tully, J. G., R. F. Whitcomb, K. J. Hackett, D. L. Rose, R. B. Henegar, J. M. Bové, P. Carle, D. L. Williamson, and T. B. Clark. 1994. Taxonomic descriptions of eight new sterol-nonrequiring mollicutes assigned to the genus Mesoplasma. Int. J. Syst. Bacteriol. 44:685-693.

35. Tully, J. G., R. F. Whitcomb, D. L. Rose, K. J. Hackett, E. Clark, R. B. Henegar, P. Carle, and J. M. Bové. 1990. Current insight into the host diversity of acholeplasmas. Zentralbl. Bakteriol. Suppl. 20:461-467.

36. Wedincamp, J., F. E. French, R. F. Whitcomb, and R. B. Henegar. Spiroplasmas and entomoplasmas (Procaryotae: Mollicutes) associated with tabanids (Diptera: Tabanidae) and fireflies (Lampyridae: Coleoptera). J. Invertebr. Pathol., in press.

37. Whitcomb, R. F. 1983. Culture media for spiroplasmas. Methods Mycoplasmol. 1:147-158.

38. Whitcomb, R. F., F. E. French, J. G. Tully, G. E. Gasparich, J. M. Bové, P. Carle, E. A. Clark, and R. B. Henegar. 1992. Tabanid spiroplasma serovars. Int. Org. Mycolplasmol. Lett. 2:115.

39. Whitcomb, R. F. and K. J. Hackett. 1995. Identification of mollicutes from insects, p. 313-322. In J. G. Tully and S. Razin (ed.), Molecular and diagnostic procedures in mycoplasmology, vol. 2. Academic Press, San Diego, Calif.

40. Whitcomb, R. F., K. J. Hackett, J. G. Tully, E. A. Clark, F. E. French, R. B Henegar, D. L. Rose, and A. G. Wagner. 1990. Tabanid spiroplasmas as a model for mollicute biogeography. Zentralbl. Bakteriol. Suppl. 20:931-933.

41. Whitcomb, R. F., J. G. Tully, D. L. Rose, E. B. Stephens, A. Smith, R. E McCoy, and M. F. Barile. 1982. Wall-less prokaryotes from fall flowers in central United States and Maryland. Curr. Microbiol. 7:285-290.

42. Williamson, D. L., J. G. Tully, D. L. Rose, K. J. Hackett, R. Henegar, P. Carle, J. M. Bové, D. E. Colflesh, and R. F. Whitcomb. 1990. Mycoplasma somnilux sp. nov., Mycoplasma luminosum sp. nov., and Mycoplasma lucivorax $\mathrm{sp}$. nov., new sterol-requiring mollicutes from firefly beetles (Coleoptera: Lampyridae). Int. J. Syst. Bacteriol. 40:160-164.

43. Williamson, D. L., J. G. Tully, L. Rosen, D. L. Rose, R. F. Whitcomb, M.-L. Abalain-Colloc, P. Carle, J. M. Bové, and J. Smyth. 1996. Spiroplasma diminutum sp. nov., from Culex annulus mosquitoes collected in Taiwan. Int. J. Syst. Bacteriol. 46:229-233.

44. Williamson, D. L., J. G. Tully, and R. F. Whitcomb. 1979. Serological relationships of spiroplasmas as shown by combined deformation and metabolism inhibition tests. Int. J. Syst. Bacteriol. 29:345-351.

45. Williamson, D. L., J. G. Tully, and R. F. Whitcomb. 1989. The genus Spiroplasma, p. 71-111. In R. F. Whitcomb and J. G. Tully (ed.), The mycoplasmas, vol. 5. Academic Press Inc., New York.

46. Williamson, D. L., R. F. Whitcomb, and J. G. Tully. 1978. The spiroplasma deformation test, a new serological method. Curr. Microbiol. 1:203-207. 